employ made possible the isolation of folic acid and of hormones such as ACTH and gastrin and of antibiotics. It is important, Professor Chain said, to have the right technique at the right time. As the isolation of penicillin required the technique of the then new freeze drying methods, so today's sophisticatcd genetical techniques are necessary to "nail down the locus of the defect" manifesting itself as disease.

The closer working of chemists with biochemists has led to discoveries in the field of natural product chemistry; for example, the elucidation of the structure of $\gamma$ globulin, or the determination of the sequence of transfer RNA.

Although these results have increased the understanding of disease they have not contributed greatly to its therapy. If the biochemist is to help medicine further he must, Professor Chain suggested, consider again the importance of comparative biochemistry. Only by viewing the intact biological system, and with the aid of his advanced techniques and sophisticated tools, can the biochemist attempt to solve the problems of incurable disease.

\section{Parliament in Britain}

\section{Hovercraft}

Mr J. P. W. Mallalieu, Minister of State in the Ministry of Technology, defended his department's policy of concentrating on the design and production of hovercraft of 300-500 tons to follow the 160 ton SRN4. Replying to suggestions that 5,000 ton hover-ships for rapid trans-atlantic freight and passenger transport, and 400 to 4,000 ton ships for communication between Scotland and northern Europe should be developed, Mr Mallalieu thought that problems associated with the smaller craft should be ironed out before work was started on larger ones. The minister said that he did not envisage active cooperation with the United States and Canada on very large ships but that a useful flow of information was being maintained. He hoped that the considerable amounts of money being spent on tracked hovercraft would keep Britain ahead in this field. (Oral answer, October 14.)

\section{Concorde}

THE first prototype Concorde aireraft is expected to fly from Toulouse early in the new year and the second about six weeks later from Filton. Mr A. Wedgwood Benn gave an assurance that there would be no political interference with the technical development of Con- corde. Replying to a question on the financial implications of the delay in the timing of the first flight, $\mathrm{Mr}$ Benn admitted that time is money, but said he believed that the in-service date would not be much affected by the initial delays.

Challenged about the danger to passengers in Concorde of exposure to galactic and solar radiation, $\mathrm{Mr}$ Benn stated that the estimated annual exposure of a Concorde crew member on North Atlantic routes is equivalent to the dose from between six and seven medical X-ray examinations. Concorde will carry an exposure monitoring device which will also give warning of the onset of exceptional solar flare radiation so that the aircraft can descend to avoid it. With this level of radiation no special shielding will be needed for the aircraft. (Oral and written answers, October 14.)

\section{Cyclamates}

IN Britain, cyclamates used in all foods and drinks except ice-cream need only be labelled as permitted artificial sweeteners. Mr Hoy, Joint Parliamentary Secretary to the Ministry of Agriculture, Fisheries and Food, declared that there was no evidence to indicate that any further restrictions should be enforced. Reminded that in the United States the Food and Drug Administration is considering compulsory detailed labelling of all products containing cyclamates, $\mathrm{Mr}$ Hoy said that the use of cyclamates was much wider in the USA than in the UK. The Food Additives and Contaminants Committee and the Pharmacological Sub-Committee found that there was no risk to health at the likely level of consumption of cyclamates. Asked if he was aware that many doctors and scientists believe sugar to be far more harmful than cyclamates, $\mathrm{Mr}$ Hoy said he did not want to start another argument. (Oral answer, October 16.)

\section{Fluoridation}

Mr K. Robinson, former Minister of Health, outlined the progress being made with the fluoridation of water supplies. For some time Anglesey, Watford and Birmingham have been supplied with fluoridated water and this year five more fluoridation schemes have started. The total population receiving fluoridated water in England and Wales now exceeds two million. In order to demonstrate complete faith in the efficacy and safety of fluoridation, the Ministry of Health will for an indefinite time pay costs for local authorities if proceedings are brought against them on grounds of injury to health caused by fluoridation. (Written answer, October 14.)

\title{
Nobel Prizes for Medicine, 1968
}

NoBody will have been in the least surprised by this year's award of the Nobel Prize for Medicine to Dr M. W. Nirenberg of the National Institutes of Health at Bethesda, Professor H. G. Khorana of Wisconsin University and Professor R. H. Holley, until recently of Cornell University and now at the Salk Institute; for several years now, all three have been strongly tipped as eventual winners of the prize. They have, of course, been central figures in the deciphering of the genetic code; in other words, in the determination of which amino-acid or punctuation mark is specified by each of the 64 three-letter code words in DNA, and in the elucidation of the process whereby this code is translated during protein synthesis.

By 1960 the general outlines of the flow of information from DNA to RNA to protein had been established, but the prospects of deciphering the code were slim. At that time the only way seemed to be by correlating 